\title{
COMMUNITY STRUCTURE AND REGENERATION STATUS OF TREE SPECIES IN KYONGNOSLA ALPINE SANCTUARY, EASTERN HIMALAYA, INDIA
}

\author{
Subhajit Lahiri ${ }^{1}$ and Sudhansu Sekhar Dash ${ }^{* 2}$ \\ ${ }^{1}$ Central National Herbarium, Botanical Survey of India, Howrah, West Bengal - 711 103, India \\ ${ }^{2}$ Botanical Survey of India, C.G.O. Complex, Salt Lake City, Kolkata, West Bengal - 700 064, India
}

Received: 8 Nov 2020, Revised: 12 October 2021, Accepted: 13 October 2021

COMMUNITY STRUCTURE AND REGENERATION STATUS OF TREE SPECIES IN KYONGNOSLA ALPINE SANCTUARY, EASTERN HIMALAYA, INDIA. Habitat destruction, over exploitation, monoculture are major reasons for loss of primary forests in Himalaya. Tree population, composition and diversity particularly in the temperate Himalaya play a key role in the maintenance of many ecosystem services and natural biogeochemical cycles. The present study explores composition and regeneration status of tree species in a temperate mixed forest in Kyongnosla Alpine Sanctuary, East Sikkim, India. Two sites at an elevation range of $2800-3800 \mathrm{~m}$ were selected and 20 plots of $20 \mathrm{~m} \times 20 \mathrm{~m}$ for trees, 80 plots of $5 \mathrm{~m}$ $\times 5 \mathrm{~m}$ for saplings, and 160 plots of $1 \mathrm{~m} \times 1 \mathrm{~m}$ for seedlings were sampled to study the regeneration status. A total of 17 tree species belonging to 9 genera and 8 families were recorded of which Rhododendron was the most dominant genus with maximum number of species. All the phytosociological attributes, such as relative density, abundance and important value index were calculated. The average species richness of adult trees and saplings was $13.5 \pm 0.7$ and for seedlings it was $12.5 \pm 0.07$. The mean density of seedlings was $3609.77 \pm 494.39$ individuals ha ${ }^{-1}$, for saplings $1540 \pm 113.13$ individuals $\mathrm{ha}^{-1}$ and of mature trees $548.75 \pm$ 8.83 individuals ha ${ }^{-1}$. Total basal area cover ranged from 36.61 to $40.35 \mathrm{~m}^{2} \mathrm{ha}^{-1}$ for trees, from 1.54 to $1.71 \mathrm{~m}^{2}$ $\mathrm{ha}^{-1}$ for saplings. Fair regeneration was observed in $64.72 \%$ of total species; good regeneration observed in $17.64 \%$ species, $11.76 \%$ species exhibited poor regeneration while $5.88 \%$ showed no regeneration. Density-diameter distribution exhibited decrease in tree densities towards higher DBH classes. The study not only provides reliable information on the ecosystem's health of the sanctuary but also will help in understanding the complexity of the ecosystem function and an approach to conservation of biota.

Keywords: Eastern Himalaya, India, Rhododendron, species richness, temperate mixed forest, tree diversity

STRUKTUR KOMUNITAS DAN STATUS REGENERASI SPESIES POHON DI KYONGNOSLA ALPINE SANCTUARY, HIMALAYA TIMUR, INDIA. Kerusakan habitat, eksploitasi berlebihan, tanaman monokultur adalah penyebab utama bilangnya butan primer di Himalaya. Populasi, komposisi dan keanekaragaman pohon khususnya di Himalaya yang beriklim sedang memainkan peran kunci dalam pemeliharaan jasa ekosistem dan siklus biogeokimia alami. Penelitian ini mengeksplorasi komposisi dan status regenerasi spesies pohon di butan campuran beriklim sedang di Kyongnosla Alpine Sanctuary, Sikkim Timur, India. Dua lokasi pada ketinggian 2800-3800 m dipilih dan 20 plot berukuran $20 m \times 20 m$ untuk,pohon, 80 plot berukuran $5 m \times 5 m$ untuk, pancang, dan 160 plot berukuran $1 \mathrm{~m} \times$ 1 m untuk. bibit diambil sampelnya untuk. dipelajari status regenerasinya. Sebanyak 17 jenis pohon dan 9 genus dan 8 famili Rhododendron tercatat sebagai genus yang paling dominan dengan jumlah spesies paling banyak. Semua atribut fitososiologis, seperti kepadatan relatif, kelimpahan dan indeks nilai penting dihitung. Rata-rata keragaman jenis pohon dewasa dan

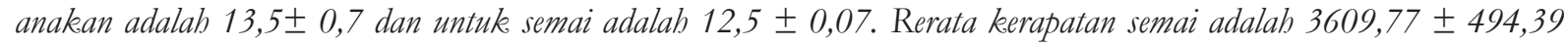
individu/ ha, untuk pancang $1540 \pm 113,13$ individu ha $a^{-1}$ dan pohon dewasa 548,75 $\pm 8,83$ individu ba $a^{-1}$. Luas dasar total tutupan pohon berkisar antara 36,61 bingga 40,35 $\mathrm{m}^{2} \mathrm{ha}^{-1}$, dari 1,54 bingga 1,71 $\mathrm{m}^{2}$ ha $\mathrm{a}^{-1}$ untuk pancang. Regenerasi yang cukup diamati pada 64,72\% dari total spesies; regenerasi yang baik diamati pada 17,64\% spesies, 11,76\% spesies menunjukkan regenerasi yang buruk, sedangkan 5,88\% tidak menunjukkan regenerasi. Distribusi kerapatan-diameter menunjukkan penurunan kerapatan pohon menuju kelas DBH yang lebib tinggi. Kajian ini tidak hanya memberikan informasi yang dapat dipercaya tentang kesehatan ekosistem cagar alam tetapi juga membantu dalam memahami kompleksitas fungsi ekosistem dan pendekatan konservasi biota.

Kata kunci: Himalaya Timur, India, Rhododendron, keragaman spesies, butan campuran beriklim sedang, keanekaragaman pobon

*Corresponding author: ssdash2002@gmail.com 


\section{INTRODUCTION}

The community structure, regeneration and stability of a forest are controlled by the density of seedlings, saplings and mature individuals of tree species (Paul, Khan, \& Das, 2018). Regeneration is an important process for the survival of tree species in a plant community under the influence of diverse environmental factors and soil conditions. In Himalaya, the regeneration of tree species particularly in sub-alpine and temperate forest ecosystems depends mainly on three factors viz. density of new seedlings at different altitude, competence of seedlings and saplings to endure under varied microclimatic condition and their ability to grow as a mature individual (Mittal, Singh \& Tewari 2020). Different tree species exhibit deficiency of adequate regeneration across the Himalayan landscape (Tewari, Bhatt, Mittal, Singh \& Tamta, 2016; Tewari, Mittal \& Singh, 2017). Therefore, knowledge on the regeneration status of any forest community is prerequisite for its management, restoration and sustainability (Pala, Negi, Gokhale, \& Todaria, 2013).

Sikkim, the second smallest state of India having an area of about $7096 \mathrm{~km}^{2}$ is known as the paradise of naturalists due to its great variety of habitats which sustains a high floral diversity. The state has estimated to have more than 5500 species of flowering plants belonging to 1371 genera under 197 families (Singh \& Sanjappa, 2011). All the representative foresttypes of eastern Himalaya like sub-Himalayan wet mixed forests, sub-tropical pine forests, wet temperate forests, mixed coniferous forests, eastern oak-Hemlock forests, Oak-fir forests, moist alpine scrubs and dry alpine scrubs are represented in Sikkim (Dash \& Singh, 2011). The temperate forest occurs between 1800 and $3500 \mathrm{~m}$ asl. It is broadly categorized as broadleaved temperate forest, mixed coniferous temperate forest. The broadleaved temperate forest characterized mostly by Acer, Castanopsis, Laurels, Magnolia, Quercus, mixed with Rhododendron species in different proportions; while the mixed coniferous forests are characterized by mixed population of Abies-Acer-Betula with Rhododendron species. The important rhododendron species which are found mixed with the coniferous trees are Rhododendron barbatum Wall. ex G. Don., Rhododendron campanulatum $\mathrm{D}$. Don., Rhododendron campylocarpum Hook.f., Rhododendron falconeri Hook. f., Rhododendron griffithianum Wight, Rhododendron thomsonii Hook. f., Rhododendron wightii Hook.f. (Lahiri \& Dash, 2021).

Recent studies show that, primary forests of this region have been increasingly under threat due to high anthropogenic disturbance (Grumbine \& Pandit 2013; Gairola, Rawal, Todaria, \& Bhatt, 2014; Malik, Hussain, Iqbal \& Bhatt, 2014; Malik, Pandey \& Bhatt, 2016; Negi, Giri \& Sekar, 2018; Haq, Rashid, Khuroo, Malik, \& Malik, 2019; Ballabha, Kuniyal, Tiwari \& Tiwari, 2020). Habitat destruction, burning and slashing agriculture, over exploitation, introduction of monoculture species are identified as major reasons for biodiversity loss (Dash, 2012). Both anthropogenic and natural disturbances are greatly affected the natural ecosystems in terms of their structure, density, composition and also their ecological processes (Allen, Breshears, \& McDowell, 2015). Prioritizing different areas for conservation based on useful trees, their mortality or regeneration along with other ecological attributes such as abundance, distribution, and dominance is need of the hour (Paul et al. 2018). Tree population particularly along higher altitudes (timberlines) play a key role in the maintenance of the natural biogeochemical cycles, vital habitats, and ecosystem services for human communities through the different provisions for life sustenance (Cobb et al., 2017). Information on the compositional attributes of vegetation such as the population structure, diversity in temperate forests of western Himalaya is adequately available (Pant \& Samant, 2012; Rawat \& Chandra, 2012; Khali \& Bhatt, 2014; Kumar \& Sharma, 2014; Malik \& Bhatt, 2015; Dar \& Sundarapandian, 2016; Malik \& Bhatt, 2016; Malik \& Nautiyal, 2016; Meena \& Rao, 2016; Kumari, Mehta, Shafi \& 
Dhiman, 2017; Mir, Masoodi, Geelani, Wani \& Sofi, 2017; Sharma, Samant, \& Lal, 2017; Bhat et al. 2020; Rawat, Tiwari, Das \& Tiwari, 2020; Dasila, Samant \& Pandey, 2021), but comprehensive account of the status of forest regeneration particularly in temperate forests in eastern Himalaya are sporadic (Yam \& Tripathi, 2016; Pandey, Badola, Rai, \& Singh, 2018; Paul et al. 2018; Sinha et al. 2018; Dash et al. 2021). Therefore, to understand the complexity of the ecosystem functions and to establish an integrated approach for conservation, reliable information on the health of these fragile ecosystems is necessary. Keeping all these in mind the present study was conceptualized with an objective to investigate the species richness and diversity, species distribution pattern, different community structure and regeneration status of tree species in temperate mixed forest of Kyongnosla Alpine Sanctuary (KAS), East Sikkim, India.

\section{MATERIAL AND METHOD}

\section{A. Study Site}

The study was carried out during 20162019 in Kyongnosla Alpine Sanctuary (KAS), East district, Sikkim, situated between $27^{\circ} 22^{\prime}$ to $27^{\circ} 24^{\prime} \mathrm{N}$ latitude and $88^{\circ} 44^{\prime}$ to $88^{\circ} 45^{\prime} \mathrm{E}$ longitude. (Figure 1). The sanctuary represents the temperate and alpine vegetation of Sikkim Himalaya and covers an area of $31 \mathrm{~km}^{2}$ with elevation ranging from $2800 \mathrm{~m}$ to $4200 \mathrm{~m}$ above mean sea level. Abies densa, Betula utilis, Lyonia ovalifolia and Rhododendron spp. are the main components in the mixed temperate forest (Table-1). The main drainage systems of the sanctuary are Byo chu, Rong chu, and Kyongnosla chu, all the rivers are fed by perennial glaciers. Depending on altitude, the sanctuary is divided into three regions viz. Rongchu (28003200 m), Goral Rock - Namnang (3200-3800 m) and Helipad-Nakchok area (>3800 m). During the present study, plots were selected

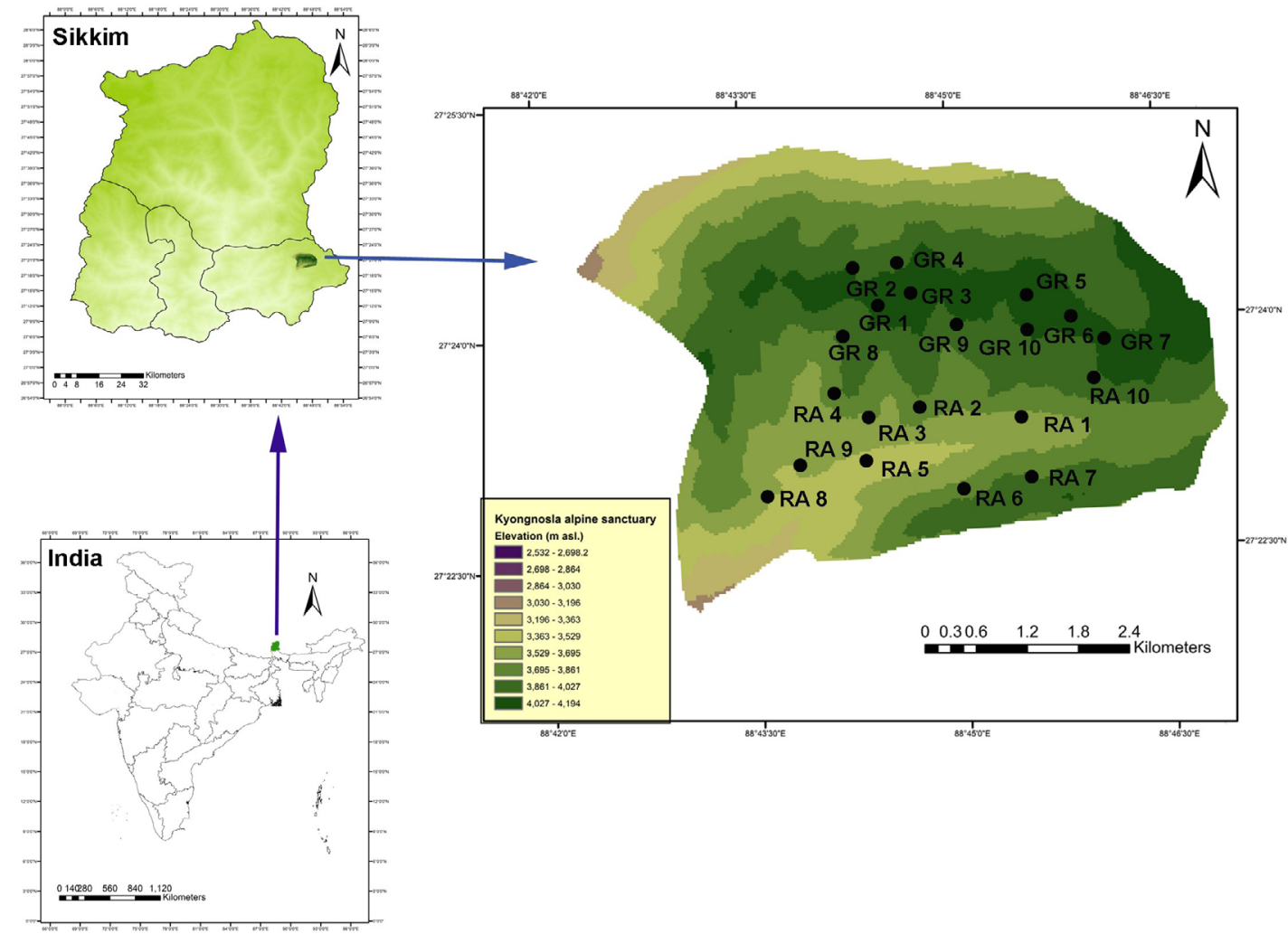

Figure 1. Map showing study site 
Table 1. General attributes of the study sites

\begin{tabular}{|c|c|c|c|c|}
\hline $\begin{array}{l}\text { S1. } \\
\text { No }\end{array}$ & $\begin{array}{l}\text { Study sites } \\
\text { (abbreviation) }\end{array}$ & $\begin{array}{l}\text { Altitude } \\
\text { (m asl) }\end{array}$ & Coordination & $\begin{array}{l}\text { Five dominant tree species } \\
\text { (IVI) }\end{array}$ \\
\hline 1. & $\begin{array}{l}\text { Rongchu } \\
\text { Site-1(RA) }\end{array}$ & $2800-3200$ & $\begin{array}{l}\text { N } 27^{\circ} 22^{\prime} 44.10^{\prime \prime} / \\
\text { E } 88^{\circ} 44^{\prime} 05.94^{\prime \prime}\end{array}$ & $\begin{array}{l}\text { Abies densa (51.92) } \\
\text { Rhododendron hodgsonii (33.85) } \\
\text { Acer caudatum (30.89) } \\
\text { Rhododendron arboreum (28.89) } \\
\text { Juniperus recurva (28.88) }\end{array}$ \\
\hline 2. & $\begin{array}{l}\text { Goral rock \& } \\
\text { Namnang } \\
\text { Site-2 (GR) }\end{array}$ & $3400-3800$ & $\begin{array}{l}\mathrm{N} 27^{\circ} 22^{\prime} 54.71^{\prime \prime} / \\
\text { E } 88^{\circ} 43^{\prime} 19.53^{\prime \prime}\end{array}$ & $\begin{array}{l}\text { Abies densa (53.54) } \\
\text { Rhododendron hodgsonii (48.54) } \\
\text { Rhododendron grande (28.67) } \\
\text { Betula utilis (26.75) } \\
\text { Acer caudatum (25.02) }\end{array}$ \\
\hline
\end{tabular}

in Rongchu (RA) and Goral Rock - Namnang (GA). Mean monthly temperature fluctuated between $0^{\circ} \mathrm{C}$ (in January) to $20^{\circ} \mathrm{C}$ (in June). The average relative humidity varies from $40 \%$ to $90 \%$ measured by digital hygrometer HTC$8 \mathrm{~A}$.

\section{B. Methods}

Field visits were undertaken regularly from July 2016 to August 2019. Phytosociological studies were carried out for three growth stages of trees i.e., mature trees, seedlings and saplings using quadrate method. The quadrates were laid in stratified random manner. For the purpose of this study, 20 sample plots i.e., 10 plots at each site of size $20 \mathrm{~m} \times 20 \mathrm{~m}$ for trees, 80 quadrates i.e., 40 quadrates at each site of size $5 \mathrm{~m} \times 5 \mathrm{~m}$ for saplings and 160 quadrates of size $1 \mathrm{~m} \times 1 \mathrm{~m}$ for seedlings (i.e., in 20 tree plots $\times 8=160$ quadrats nested within each tree plot) were laid down on the forest floor. The correctness of sample size was determined by reaching the point when additional quadrats did not significantly add any new species. Individual tree species having $>30 \mathrm{~cm}$ circumferences at breast height ( $\mathrm{CBH}$ i.e., $1.37 \mathrm{~m}$ above ground) considered as mature trees and were measured species wise. Individuals having $<10 \mathrm{~cm} \mathrm{CBH}$ were considered as seedlings and individuals having $\mathrm{CBH}$ intermediate in between above two classes are considered as saplings (Malik
$\&$ Bhatt, 2015). Circumference at breast height $(\mathrm{dbh}=1.37 \mathrm{~m})$ was calculated as $\pi \mathrm{r}^{2}$ (where $\mathrm{r}$ is the radius). Basal area ( $\left.\mathrm{m}^{2} / \mathrm{ha}-\right)$ was used to determine the relative dominance of a tree species.

\section{Data Analysis}

All collected plant specimens were identified with the help of available literature (Bhattacharyya \& Sanjappa, 2014; Panda \& Sanjappa, 2014; Mao, Dash, \& Singh, 2017; Maity, Maiti, \& Chauhan, 2018) and also by consulting different herbaria (ARUN, ASSAM, BSHC and CAL). Voucher specimen were prepared following standard procedure (Jain \& Rao, 1977) and deposited at Central National Herbarium (CAL). The phytosociological parameters i.e., frequency, density, abundance, total basal area, and their relative values were calculated from pooled quadrate data (Misra, 1968).

Importance value index (IVI) was calculated by summing up the relative values of density (RD), frequency (RF), and total basal (TBA) area (Misra, 1968). If a species contributed $\geq 50 \%$ of the total IVI in a particular site/ habitat that site was considered a single species dominated community and if $<50 \%$ of the total IVI, a mixed community. Species richness was determined as the number of species per unit area (Whittaker, 1972). The distribution pattern 
was determined by the ratio of abundance to frequency. This ratio indicates regular $(<0.025)$, random (0.025 to 0.05$)$ and contagious $(>0.05)$ distributions (Odum, 1971). Regeneration status of species was totally based on population size of seedlings and saplings (Malik \& Bhatt, 2016; Sharma, Mishra, Tiwari, Krishan, \& Rana, 2018). Good regeneration is when a species is present in seedlings $>$ saplings $>$ mature stages; fair regeneration, when species is present in seedlings $>$ saplings < mature stage; poor regeneration, when the species is present only in sapling stage, but not as seedlings. When a species is present only in mature stage it is considered as not regenerating. Species is considered as new if the species has no adults but only seedlings or saplings.

The diversity $\left(\mathrm{H}^{\prime}\right)$ was determined by using Shannon-Wiener information index (Shannon \& Weaver, 1963) as:

$\mathrm{H}^{\prime}=-\sum \mathrm{n}_{\mathrm{i}} / \mathrm{n} \log _{2} \mathrm{n}_{\mathrm{i}} / \mathrm{n}$

where, ni was the IVI value of a species and $n$ was the sum of total IVI values of all species in that forest type. Simpson's diversity index (Simpson, 1949) was calculated as:

$\mathrm{D}=1-\mathrm{Cd}$,

where, $\mathrm{D}=$ Simpson's diversity and $\mathrm{Cd}=$ Simpson's concentration of dominance $=\left(\sum \mathrm{ni}\right.$ $/ \mathrm{n})^{2}$. Species evenness was calculated using the
Shannon evenness index:

$J^{\prime}=H^{\prime} / l_{n}(\mathrm{~S})$

where $\mathrm{H}^{\prime}$ is the Shannon- Wiener diversity index and $\mathrm{S}$ is the number of species (Pielou, 1966).

The Shannon evenness index ranges from 0 (when one species is dominant) to 1 (when all species are equally abundant). Beta diversity (Whittaker, 1972) was calculated using the formula:

$\beta$-diversity $=\left(\mathrm{S}_{1}-\mathrm{c}\right) /\left(\mathrm{S}_{2}-\mathrm{c}\right)$

where $\mathrm{S} 1$ is the total number of species in site 1 and $\mathrm{S} 2$ total number of species in site 2, $\mathrm{c}$ is the total number of species occurring in both sites. Species area curve were calculated using PCCORD V. 7 (McCune \& Mefford, 2016). Species area curve was used to evaluate the adequacy of sample size in the plant community.

\section{RESULT AND DISCUSSION}

\section{A. Species Richness and Diversity}

A total of 17 tree species belonging to 9 genera and 8 families were recorded from two sampling sites RA [Site-1] and GR [Site-2] (Table 5). Rhododendron with 9 species was the dominant genus. The consolidated phytosociological attributes and diversity indices of studied forest stands are shown in Table 2. Species area curve (Figure 2) revealed that, 10 plots yielded over 14

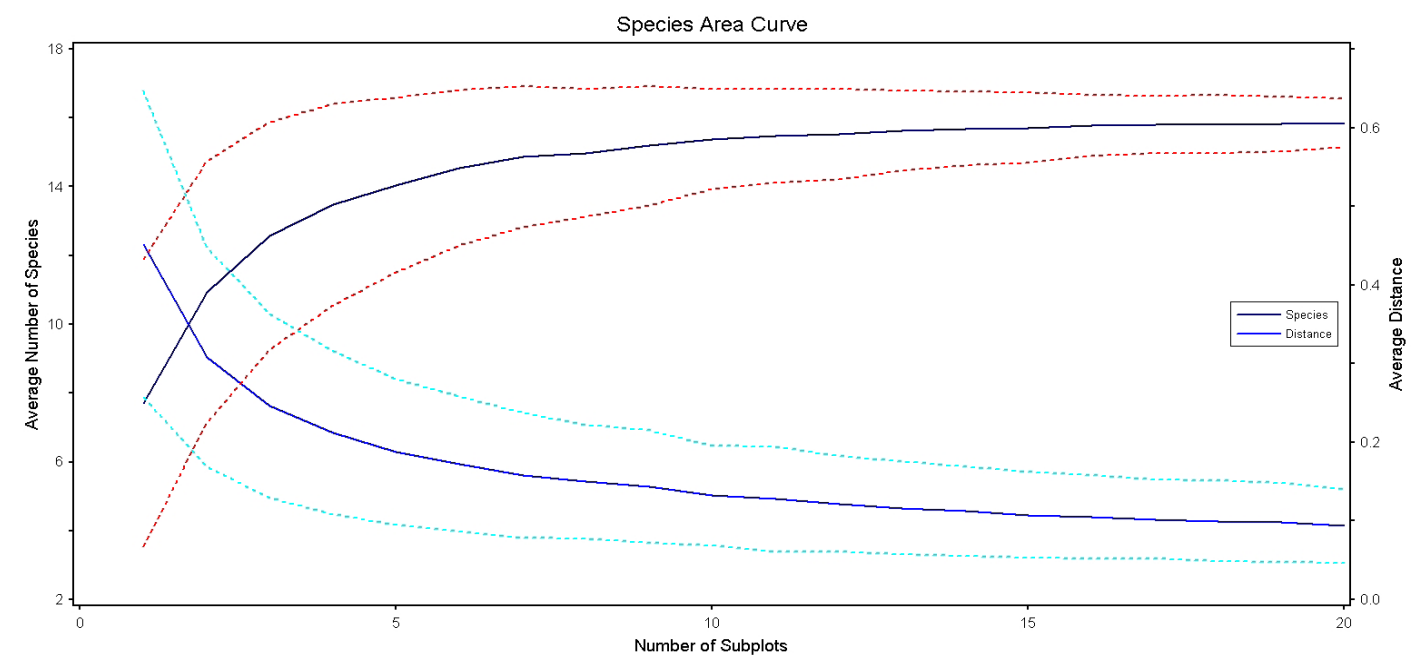

Figure 2. Species area curve based on repeated sub-sampling of a fixed sample (20 sample unit and 17 species) 
species, with more plots yielded relatively small increase in the number of species. Similarly, 10 plots yielded a Sorensen distance of less than $0.1(<10 \%)$, measured between the centroid of the subsample and the centroid of the whole sample.

Analysis of phytosociological attributes like density, basal area (BA), importance value index (IVI) for each growth form such as trees, saplings and seedlings (Table-3) for each site revealed that, species richness of trees varied from 13-14 (13.5 \pm 0.70), saplings 13-14 (13.5 $\pm 0.70)$ and seedlings $13-12(12.5 \pm 0.70)$. Total tree density was minimum and varied between 542.5-555 ha-1 (548.75 \pm 8.83$)$, saplings density was moderate and varied between 1460-1620 $\mathrm{ha}^{-1}(1540 \pm 113.13)$, while the seedlings density was maximum with 3115.38-4104.16 $\mathrm{ha}^{-1}$ (3609.77 \pm 494.39$)$. Tree basal area recorded a maximum $\left(40.35 \mathrm{~m}^{2} \mathrm{ha}^{-1}\right)$ at site 1 (RA) and minimum $\left(36.61 \mathrm{~m}^{2} \mathrm{ha}^{-1}\right)$ at site $2(\mathrm{GR})$. Average basal area per site for trees, saplings and seedlings were $38.48 \pm 2.64 \mathrm{~m}^{2} \mathrm{ha}^{-1}, 1.62 \pm 0.12$ $\mathrm{m}^{2} \mathrm{ha}^{-1}$ and $0.86 \pm 0.04 \mathrm{~m}^{2} \mathrm{ha}^{-1}$, respectively. These values obtained during the present study are comparable to earlier studies carried out in other Himalayan ecosystems.
Gairola et al., (2008), reported tree density of $552.88 \pm 57.92$ individuals ha $^{-1}$, sapling density $4935.44 \pm 706.62$ individuals $\mathrm{ha}^{-1}$ and seedling density $3375.51 \pm 1125.17$ individuals $\mathrm{ha}^{-1}$ in subalpine forest dominated by abies-quercus community in Western Himalaya. Rawat et al., (2018), reported tree density of $248.5 \pm$ 22.79 individuals $\mathrm{ha}^{-1}$, sapling density $840 \pm$ 141.07 individuals $\mathrm{ha}^{-1}$, and seedling density $32278.6 \pm 3712.1$ individuals ha $^{-1}$ from mixed type subtropical forest of eastern Himalaya that is smaller value than present reported value which indicates that high mortality rate of saplings in subtropical forest might be due to dense canopy coverage. Singh et al. (2016), who were studying regeneration status of tree species of temperate oak dominated forest of Garhwal Himalaya recorded seedling density ranging from 1376-9600 individuals/ha. Deb and Sundriyal (2008) reported seedling density of $8619 \pm 4106.86$ individuals $\mathrm{ha}^{-1}$ from subtropical forest of Namdapha National Park.

The total basal area ranged from $36.61 \pm$ $0.87 \mathrm{~m}^{2} \mathrm{ha}^{-1}$ (GR) to $40.35 \pm 0.77 \mathrm{~m}^{2} \mathrm{ha}^{-1}$ (RA). These values are much higher to similar studies conducted in western Himalaya, viz., 8.94-69.84 $\mathrm{m}^{2} \mathrm{ha}^{-1}$ as reported by Gairola et al. (2008); $18 \pm$

Table 2. Phytosociological attributes and diversity indices of the study sites

\begin{tabular}{|c|c|c|c|c|c|c|}
\hline \multirow[t]{2}{*}{ Variables } & \multicolumn{2}{|c|}{ Trees } & \multicolumn{2}{|c|}{ Saplings } & \multicolumn{2}{|c|}{ Seedlings } \\
\hline & $\begin{array}{l}\text { Site-1 } \\
\text { (RA) }\end{array}$ & $\begin{array}{l}\text { Site-2 } \\
(\mathrm{GR})\end{array}$ & $\begin{array}{l}\text { Site-1 } \\
\text { (RA) }\end{array}$ & $\begin{array}{l}\text { Site-2 } \\
\text { (GR) }\end{array}$ & $\begin{array}{l}\text { Site-1 } \\
\text { (RA) }\end{array}$ & $\begin{array}{l}\text { Site-2 } \\
\text { (GR) }\end{array}$ \\
\hline No. of plots & 10 & 10 & 40 & 40 & 80 & 80 \\
\hline Size of plots $\left(\mathrm{m}^{2}\right)$ & 400 & 400 & 25 & 25 & 01 & 01 \\
\hline Actual sampled area (ha) & 0.80 & 0.80 & 0.10 & 0.10 & 0.008 & 0.008 \\
\hline No. of species & 14 & 13 & 14 & 13 & 13 & 12 \\
\hline No. of genera & 7 & 9 & 7 & 7 & 6 & 7 \\
\hline No. of families & 7 & 8 & 7 & 7 & 6 & 6 \\
\hline $\begin{array}{l}\text { Density (individuals } \\
\mathrm{ha}^{-1} \text { ) }\end{array}$ & 555 & 542.5 & 1620 & 1460 & 40500 & 49250 \\
\hline Basal Area $\left(\mathrm{m}^{2} \mathrm{ha}^{-1}\right)$ & 40.35 & 36.61 & 1.11 & 1 & 0.89 & 0.83 \\
\hline Diversity index & 0.55 & 0.51 & 0.60 & 0.58 & 0.57 & 0.52 \\
\hline Beta diversity ( $\beta$ - Div.) & 1.64 & 1.52 & 1.64 & 1.30 & 1.52 & 1.41 \\
\hline $\begin{array}{l}\text { Concentration of } \\
\text { dominance }(\mathrm{Cd})\end{array}$ & 0.095 & 0.10 & 0.077 & 0.079 & 0.082 & 0.094 \\
\hline Evenness (e) & 0.48 & 0.46 & 0.52 & 0.52 & 0.51 & 0.48 \\
\hline
\end{tabular}


Table 3. Phytosociological attributes of two study sites of Kyongnosla Alpine Sanctuary

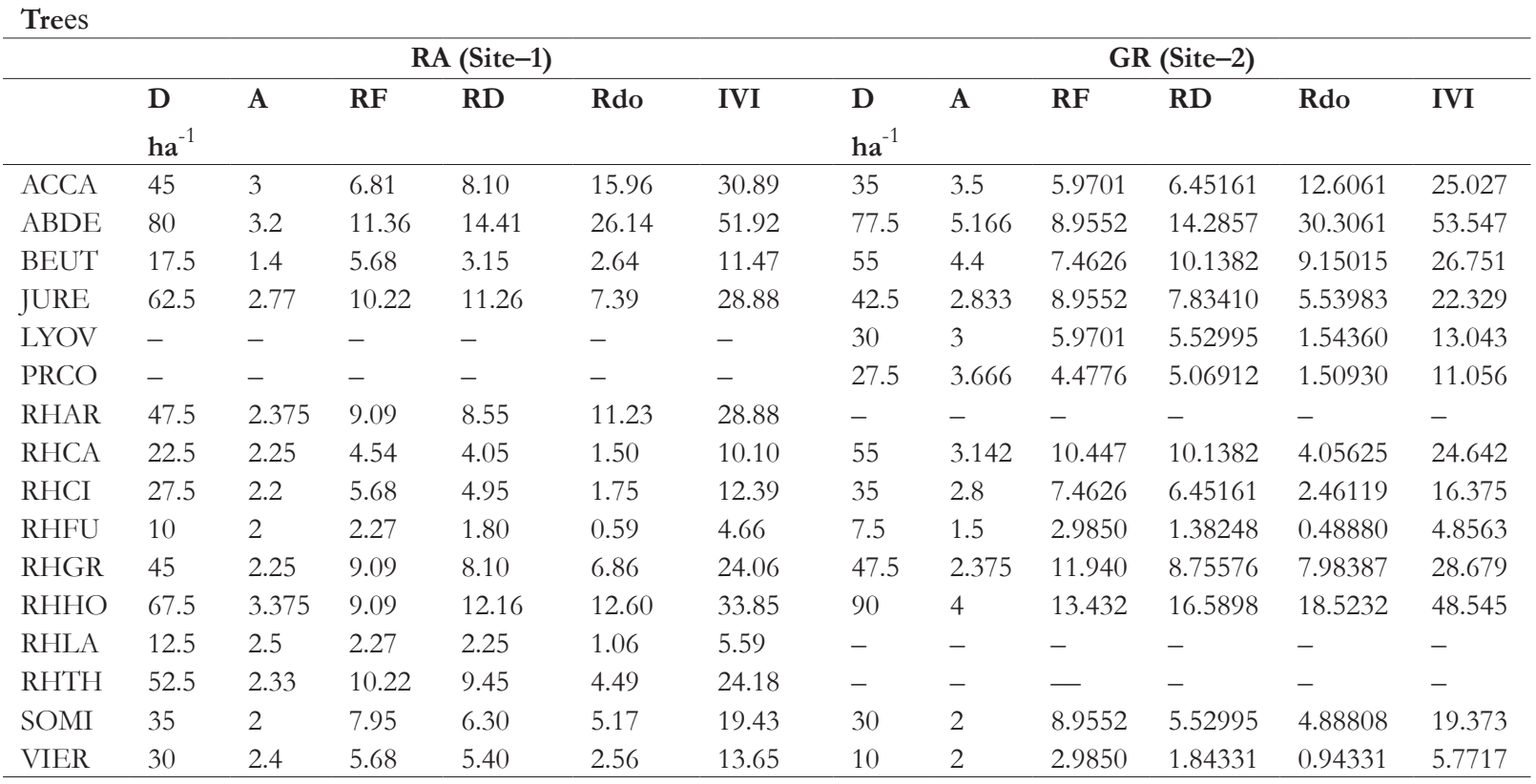

Saplings

\begin{tabular}{lllllllllllll}
\hline \multicolumn{9}{c}{ RA (Site-1) } \\
\hline & $\mathbf{D}$ & $\mathbf{A}$ & $\mathbf{R F}$ & $\mathbf{R D}$ & $\mathbf{R d o}$ & $\mathbf{I V I}$ & $\mathbf{D}$ & $\mathbf{A}$ & $\mathbf{R F}$ & $\mathbf{R D}$ & Rdo & IVI \\
& $\mathbf{h a}^{-1}$ & & & & & & & & & & \\
$\mathbf{h a}^{-1}$ & & & & & & & \\
\hline ACCA & 90 & 1.28 & 5.55 & 5.83 & 7.72 & 19.11 & 80 & 1.33 & 6.59 & 5.47 & 8.53 & 20.61 \\
ABDE & 130 & 1.18 & 8.02 & 9.16 & 10.97 & 28.16 & 150 & 1.66 & 9.89 & 10.27 & 12.13 & 32.29 \\
BEUT & 140 & 1.55 & 8.64 & 7.5 & 6.91 & 23.05 & 110 & 1.37 & 8.79 & 7.53 & 7.64 & 23.96 \\
JURE & 160 & 1.14 & 9.87 & 11.66 & 6.09 & 27.64 & 130 & 1.85 & 7.69 & 8.90 & 6.74 & 23.33 \\
RHAR & 110 & 1.375 & 6.79 & 6.66 & 8.13 & 21.58 & - & - & - & - & - & - \\
RHCA & 90 & 1.28 & 5.55 & 5.83 & 7.31 & 18.70 & 130 & 1.44 & 9.89 & 8.90 & 8.08 & 26.88 \\
RHCI & 90 & 1.5 & 5.55 & 5 & 6.50 & 17.05 & 80 & 1.33 & 6.59 & 5.47 & 7.19 & 19.26 \\
RHFU & 110 & 1.22 & 6.79 & 7.5 & 5.69 & 19.98 & 90 & 2.25 & 4.39 & 6.16 & 6.29 & 16.85 \\
RHGR & 140 & 2 & 8.64 & 5.83 & 5.69 & 20.16 & 140 & 1.75 & 8.79 & 9.58 & 6.29 & 24.67 \\
RHHO & 170 & 1.133 & 10.49 & 12.5 & 9.34 & 32.34 & 140 & 1.55 & 9.89 & 9.58 & 10.33 & 29.81 \\
RHLA & 110 & 2.2 & 6.790 & 4.16 & 7.11 & 18.07 & 110 & 1.57 & 7.69 & 7.53 & 7.86 & 23.09 \\
RHTH & 190 & 1.18 & 11.72 & 13.33 & 5.081 & 30.14 & 100 & 1.25 & 8.79 & 6.84 & 5.61 & 21.25 \\
SOMI & 60 & 1.5 & 3.70 & 3.33 & 7.52 & 14.55 & 90 & 1.8 & 5.49 & 6.16 & 8.31 & 19.7 \\
\hline
\end{tabular}

Seedlings

\begin{tabular}{|c|c|c|c|c|c|c|c|c|c|c|c|c|}
\hline & \multicolumn{6}{|c|}{ RA (Site-1) } & \multicolumn{6}{|c|}{ GR (Site-2) } \\
\hline & D & A & RF & RD & Rdo & IVI & $\mathbf{D}$ & A & RF & RD & Rdo & IVI \\
\hline & $\mathbf{h a}^{-1}$ & & & & & & $\mathbf{h a}^{-1}$ & & & & & \\
\hline ACCA & 2125 & 1.41 & 5.50 & 5.24 & 8.14 & 18.89 & 3000 & 1.14 & 7.55 & 6.09 & 8.75 & 22.39 \\
\hline $\mathrm{ABDE}$ & 3875 & 1.192 & 11.92 & 9.56 & 9.82 & 31.31 & 7250 & 1.34 & 15.46 & 14.72 & 10.55 & 40.73 \\
\hline BEUT & 1875 & 1.66 & 4.12 & 4.62 & 7.58 & 16.34 & 2625 & 2.33 & 3.23 & 5.32 & 8.15 & 16.72 \\
\hline JURE & 5875 & 1.424 & 15.13 & 14.5061 & 7.47767 & 37.1214 & 7625 & 1.41 & 15.46 & 15.48 & 8.03 & 38.98 \\
\hline PRCO & - & - & - & - & - & - & 2375 & 1.35 & 5.03 & 4.82 & 8.27 & 18.13 \\
\hline RHAR & 3625 & 1.611 & 8.25 & 8.95061 & 7.8125 & 25.0199 & - & - & - & - & - & - \\
\hline RHCA & 3250 & 2.166 & 5.50 & 8.02469 & 7.36607 & 20.8953 & 3625 & 1.61 & 6.47 & 7.36 & 7.91 & 21.74 \\
\hline RHCI & 4625 & 1.275 & 13.30 & 11.4197 & 7.03125 & 31.7537 & 3250 & 2.166 & 4.316 & 6.59 & 7.55 & 18.46 \\
\hline RHFU & 2625 & 1.909 & 5.045 & 6.48148 & 6.69642 & 18.2237 & - & - & - & - & - & - \\
\hline RHGL & - & - & - & - & - & - & 2525 & 1.5 & 5.03 & 5.32 & 7.55 & 17.91 \\
\hline RHGR & 2375 & 1.357 & 6.422 & 5.86419 & 7.92410 & 20.2103 & 4625 & 1.27 & 10.43 & 9.39 & 8.51 & 28.33 \\
\hline RHHO & 2000 & 1.6 & 4.587 & 4.93827 & 8.14732 & 17.6727 & 7000 & 1.14 & 17.62 & 14.21 & 8.75 & 40.59 \\
\hline
\end{tabular}


Table 3. Continued

\begin{tabular}{lllllllllllll}
\hline \multicolumn{19}{c}{ RA (Site-1) } & \multicolumn{1}{c}{ GR (Site-2) } \\
& $\begin{array}{l}\text { D } \\
\text { ha }^{-1}\end{array}$ & $\mathbf{A}$ & RF & RD & Rdo & IVI & D & A & RF & RD & Rdo & IVI \\
RHLA & 3250 & 1.625 & 7.339 & 8.02469 & 7.14285 & 22.5069 & - & - & - & - & - & - \\
\hline RHTH & 2625 & 1.5 & 6.422 & 6.48148 & 6.91964 & 19.8231 & 2000 & 1.6 & 3.59 & 4.06 & 7.43 & 15.09 \\
SOMI & 2375 & 1.357 & 6.422 & 5.86419 & 7.92410 & 20.2103 & 3250 & 1.62 & 5.75 & 6.59 & 8.51 & 20.86 \\
\hline
\end{tabular}

Abbreviations: Abies densa :- ABDE, Acer caudatum = ACCA, Betula utilis = BEUT, Juniperus recurva = JURE, Lyonia ovalifolia $=\mathrm{LYOV}$, Prunus cornuta $=$ PRCO, Rhododendron arboreum $=$ RHAR, Rhododendron campylocarpum $=$ RHCA, Rhododendron cinnabarinum $=$ RHCI, Rhododendron fulgens $=$ RHFU, Rhododendron glaucophyllum $=$ RHGL, Rhododendron grande $=$ RHGR, Rhododendron hodgsonii $=$ RHHO, Rhododendron lanatum $=$ RHLA, Rhododendron thomsonii $=$ RHTH, Sorbus microphylla $=$ SOMI, Viburnum erubescens $=$ VIER, $\mathrm{A}=$ Abundance, $\mathrm{D} \mathrm{ha}^{-1}=$ Density (individuals $\mathrm{ha}^{-1}$ ), $\mathrm{RF}=$ Relative frequency, $\mathrm{RD}=$ Relative density, Rdo $=$ Relative dominance, IVI $=$ Important value index

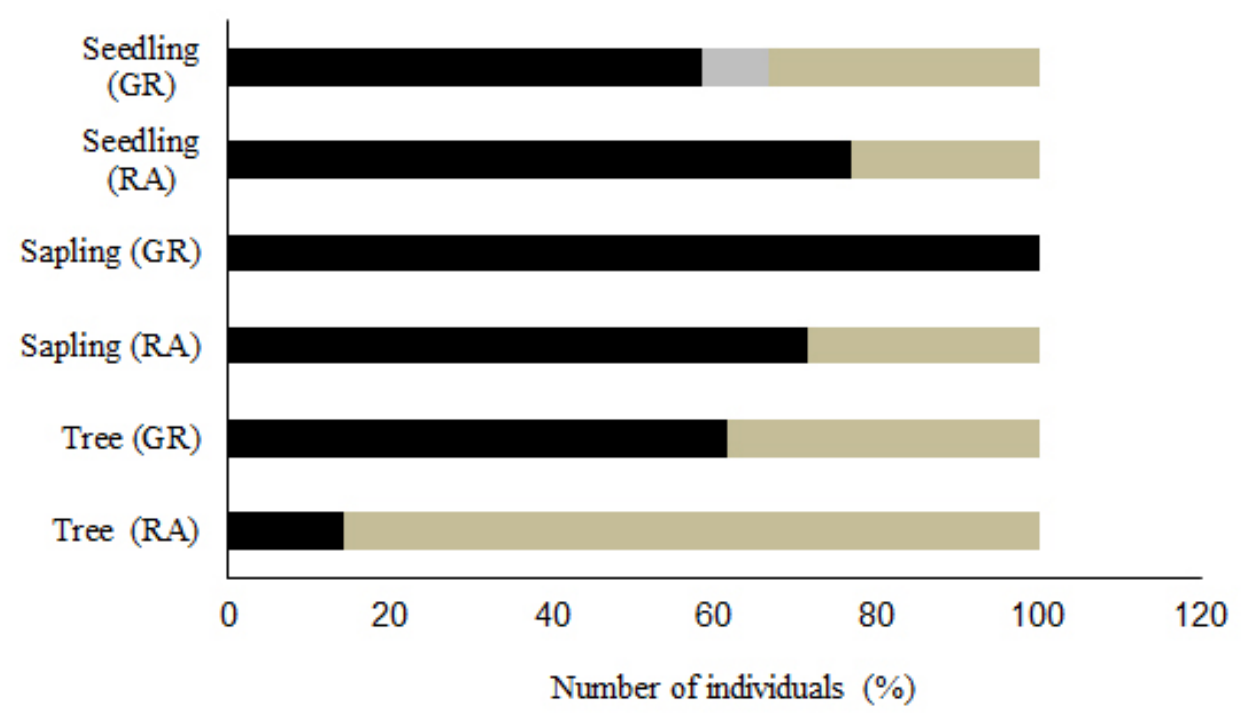

Figure 3. Distributions pattern of trees, saplings and seedlings at both study sites

$10.69 \mathrm{~m}^{2}$ ha-1 as reported by Rawat et al., (2018) and higher to the result in ridge forests of the western Himalaya Tiwari et al. (2018) $61.09 \pm$ $9.35 \mathrm{~m}^{2} \mathrm{ha}^{-1}$ ). The higher value might be due to the high floral diversity particularly the broad leaved elements in eastern Himalaya. This also substantiate the fact that, in the temperate to subalpine forests of Sikkim Himalaya (2800$3800 \mathrm{~m}$ asl.) high density of low girth class tree species such as Rhododendrons, Sorbus, Viburnum etc. record maximum diversity in the middle storey while in the top storey just a limited number of coniferous such as Abies densa is found. Beside the altitudinal variation; species composition, age structure and successional stage of the forest also affect the basal area of the tree species. Concentration of dominance (cd) ranged from 0.09 (RA) -0.10 (GR) in tree, 0.07 in sapling and $0.08-0.09$ in seedling layer. In the present study concentration of dominance of the entire landscape community is strongly influenced by the important value index of the first three relatively important species as similarly observed in western Himalayan subtropical forest (Malik \& Bhatt, 2015). This is because of the concentration of the dominance is generally inversely proportionate to species diversity and species richness.

\section{B. Species Distribution Pattern}

Abundance to frequency (A/F) ratio for the tree stratum indicated that majority of the tree 
species in all growth stages showed contiguous distribution pattern (Figure 3), while most of the random distribution pattern recorded in site-1 but only few species among seedlings at site-2 (GR) shows random distribution (Figure 3). Abies densa was the dominant tree species in both study area Rongchu (RA) (Site1) and Goral rock (GR) (Site-2) with important value index 51.92 and 53.54 respectively. The other dominant species in RA were Rhododendron hodgsonii (IVI: 33.85) followed by Acer caudatum (IVI: 30.89), Juniperus recurva (IVI: 28.88), Rhododendron arboreum (IVI: 28.88) and in GR Rhododendron hodgsonii (IVI: 48.54) followed by Rhododendron grande (IVI: 28.68), Betula utilis (IVI: 26.75), Acer caudatum (IVI: 25.02), Rhododendron campylocarpum (IVI: 24.64).

In saplings stratum, Rhododendron hodgsonii (IVI: 32.34) was the dominant species at RA and Abies densa (IVI: 32.29) at GR. Similarly, among seedlings, Juniperus recurva had maximum spread out (IVI: 37.1) at RA followed by Rhododendron cinnabarinum (IVI: 31.8), Abies densa (IVI: 31.3), Rhododendron arboreum (IVI: 25). Abies densa was the most dominant (IVI: 40.74) species at GR followed by Rhododendron hodgsonii (IVI: 40.59), Juniperus recurva (IVI: 38.98), Rhododendron grande (IVI: 28.33). Rhododendron glaucophyllum (IVI: 17.91) was observed only in seedling stage at GR. The dominance-diversity curve (d-d curve) in all three stages i.e., mature tree, sapling and seedling layers (based on $\log 10$ value of IVI) were of normal log series (Figure 4).

Shannon-Wiener diversity index $\left(\mathrm{H}^{\prime}\right)$ of tree species ranged from 0.51 (GR) to 0.55 (RA), for sapling $\mathrm{H}^{\prime}$ ranged from 0.58 (GR) to $0.60(\mathrm{RA})$ and for seedling it ranged from 0.52 (GR) to
0.57 (RA). Lower diversity indices imply that temperate to sub- alpine forest of Kyongnosla Alpine Sanctuary is homogeneous. It is mainly dominated by different species of Rhododendron and Abies. It also indicates that species may not coexist in an overlapping habitat that in turn gives lower stability of the forest. These values of $\mathrm{H}^{\prime}$ are smaller than values reported from temperate forest of Khokhan Wildlife Sanctuary, north-western Himalaya (Pant \& Samant, 2012), which might be due to difference in altitudinal gradient, vegetational composition suitability to habitats. In the timberline zone of Khangchendzonga National Park, Sikkim, $\mathrm{H}^{\prime}$ value for tree was observed between 0.77-1.47 and 1.2-1.9 respectively (Pandey, Badola, Rai, \& Singh, 2018; Pandey, Rai, \& Kumar, 2018) which were higher value than in the present study. The lower value of the present study may be attributed to the presence of homogeneous forest in eastern part of Sikkim Himalaya than in the western part. The Bhutanese affinities of plant in the eastern part and central Nepalese affinities in the western part also play a role in topography and local landscape label. As compared in Quercus-Cedrus dominated ridge temperate forest in western Himalaya $\mathrm{H}^{\prime}$ the diversity was $0.51 \pm 0.05$ (Tiwari et al., 2018).

The values of Pielou equitability ranged from 0.46 to 0.48 in tree layer, 0.52 in sapling layer and 0.48 to 0.51 in seedling layer which is larger than $(0.30-0.36$ for trees, $0.3-0.40$ for saplings, and 0.32-0.41 for seedlings) of mixed forest of Western Himalaya for the same functional group (Tiwari et al., 2018); while lower than $(1.15 \pm 0.20$ for tree, $1.24 \pm 0.03$ for sapling and $1.21 \pm 0.04$ for seedlings) in the

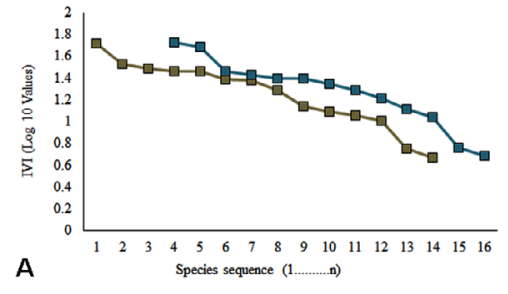

A. Trees

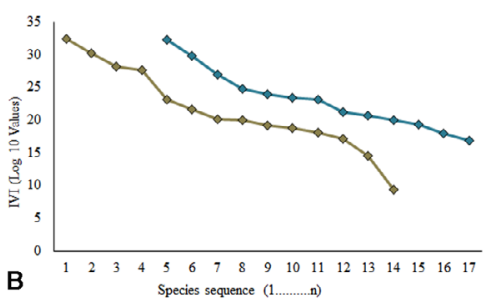

B. Saplings and

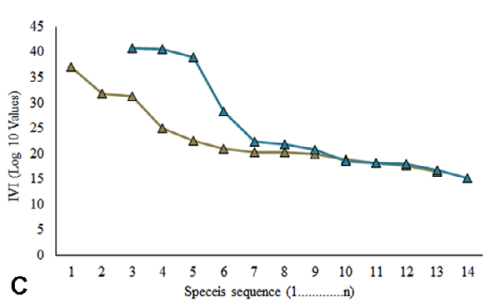

C. Seedlings

Figure 4. Dominance-diversity curves (d-d curve) 
temperate forest of eastern Himalaya (Rawat et al., 2018). The moderate value for this evenness index can be attributed to the higher diversity of one genus Rhododendron in Site 1 (RA) and diversification or low diversity assemblage of the same genus in Site 2 (GR).

The extent of species replacement or species turnover along environmental gradient in the studied area determinates its beta diversity. The study shows that the beta diversity for tree layer ranged from 1.21 to 1.52; for sapling 1.64 (RA) to 1.52 (GR). Low differences in the values of beta diversity among different sites indicate that different growth form respond in a similar fashion and species composition does not vary significantly across different forest types (Adhikari, Rikhari, Rawat, \& Singh, 1991). The species composition of Conifers- Rhododendron mixed temperate or subalpine forest shows the uniform community assembly because of their inclination to grow in pure patches or availability of limited number of broad-leafed elements in mixed forest across the study area.

\section{Regeneration Status}

The regeneration status of each tree species at different study sites are presented in Table 5. Proportion of regeneration status is shown in Figure 5. Fair regeneration status was recorded for maximum species at both sites. Density-diameter distribution exhibited decrease in tree densities towards higher DBH classes. Maximum tree individuals (64.7\%) were observed in the fair regeneration area, followed by $17.64 \%$ of good regeneration, $11.76 \%$ of poor regeneration and $5.88 \%$ as new. Most tree individuals $(45.82 \%)$ were observed in the least $\mathrm{DBH}$ class $(<10 \mathrm{~cm})$, followed by $>30$ $\mathrm{cm}(28.58 \%)$ and $10-30 \mathrm{~cm}(25.59 \%)$ (Figure 6). Regeneration is not observed in Viburnum erubescens in all sites probably due to poor seed viability or non-conducive habitat.

Overall regeneration status of the studied temperate mixed forest in Kyongnosla Alpine Sanctuary possesses fair regeneration rate which varied from $14.28 \%$ (RA) to $76.92 \%$ (GR). Abies densa is the dominant tree species in both sites and shows fair regeneration. Lyonia ovalifolia and Rhododendron fulgens, R. hodgesonii and Viburnum erubescens at GR show poor regeneration. Viburnum erubescens was not regenerating at all at RA while Rhododendron glaucophyllum at GR was found only in seedling stage. The high density of Abies and Rhododendron in both the studied

Table 5. Regeneration status of tree species in study area

\begin{tabular}{lcc}
\hline \multirow{2}{*}{ Name of species } & \multicolumn{2}{c}{ Study sites } \\
\cline { 2 - 3 } & Site-1 (RA) & Site-2 (GR) \\
\hline Abies densa Griff. & No & Fair \\
Acer caudatum Wall. & No & Fair \\
Betula utilis D. Don & Good & Fair \\
Juniperus recurva Buch. -Ham. ex D. Don & Fair & Fair \\
Rhododendron arboreum Sm. & Fair & - \\
Rhododendron campylocarpum Hook. f. & Good & Fair \\
Rhododendron cinnabarinum Hook. f. & Fair & Fair \\
Rhododendron fulgens Hook. f. & Good & Poor \\
Rhododendron glaucophyllum Rehder & - & New \\
Rhododendron grande Wight & Fair & Fair \\
Rhododendron hodgsonii Hook. f. & No & Fair \\
Rhododendron lanatum Hook. f. & Good & New \\
Rhododendron thomsonii Hook. f. & Good & No \\
Sorbus microphylla (Wall. ex Hook.f.) Wenz. & Fair & Fair \\
Lyonia ovalifolia (Wall.) Drude & - & Good \\
Prunus cornuta (Wall. ex Royle) Steud. & - & Poor \\
Viburnum erubescens Wall. & No & No \\
\hline
\end{tabular}




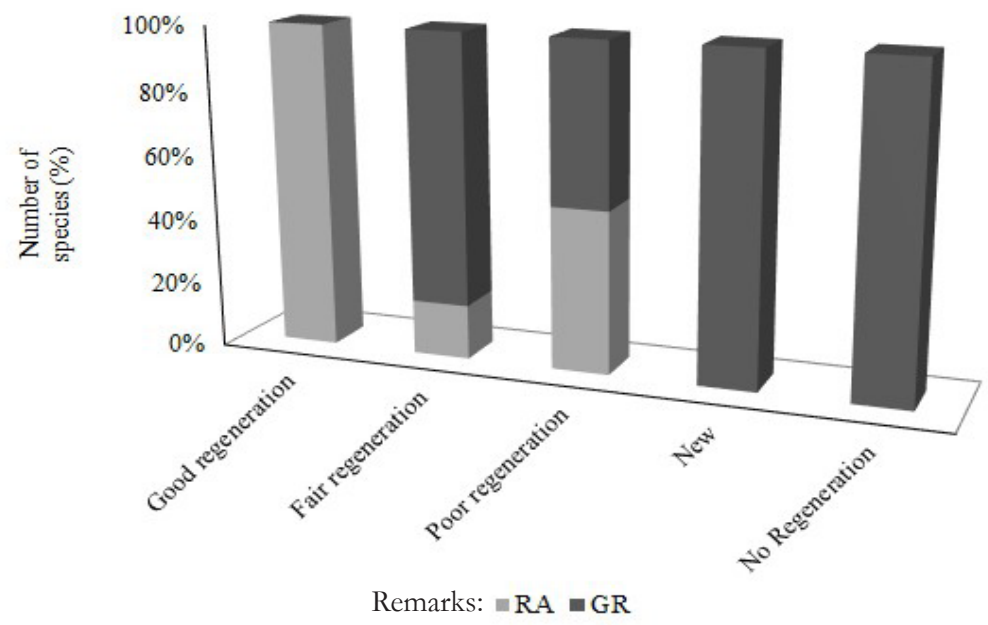

Figure 5. Regeneration status of tree species at various study sites

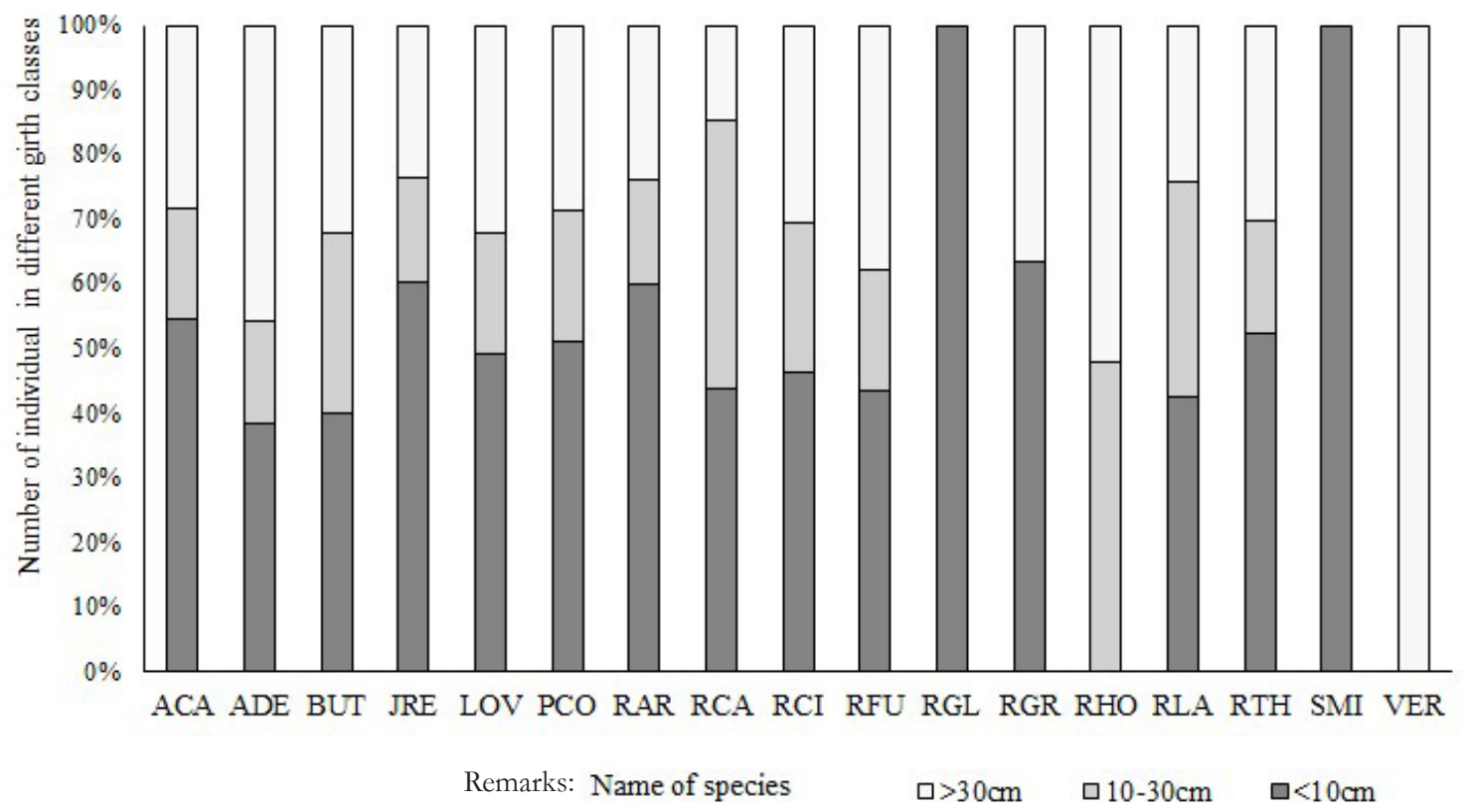

Figure 6. Distributions of tree individuals in different diameter classes

sites may be attributed to the optimal $\mathrm{pH}$ value (nearer to 5.5) of the soil for the growth of these two species (Sundriyal \& Bisht, 1988).

The variations in phytosociological attributes in different Himalayan Forests can be attributed to the influence by large number of environmental variables e.g., soil conditions, slope angle, species composition, elevation, regional climate, topography and anthropogenic interferences (Das et al., 2020). The variations in the different successional stages of the studied sites can be ascribed to both locality and landscape-level variations in forest attributes, thus producing spatial heterogeneity (Rawat et al., 2020). In the present study, we have also observed that, species richness of trees and saplings was recorded a maximum at Study site 2 (GR); tree density, species richness and basal area followed a trend of decreasing (from RA-GR) with increasing altitude. Maximum 
basal area of trees and saplings were recorded at lower altitude (RA) and minimum at upper altitude (GR).

The general regeneration pattern of tree species in the study area was fairly high. The study sites are also part of one of the highly diversified alpine forests of Sikkim Himalaya, and it is covered under the protected area network. However, the rich floristic resources of the area have considerably depleted both quantitatively as well as qualitatively in the recent times owing to the illegal encroachments, influx of tourism, unscientific over exploitation of medicinal plants, and heavy grazing. During the study, it has also been observed that, plants are highly effected due to overuse grazing and browsing by taks of adjacent villages, many plants species have suffered with depleted regeneration. Therefore, keeping view of the sustainability of the alpine sanctuary and to preserve the plant wealth, the forest department of Sikkim have already been implementing various conservation programmes such as controlled grazing, development of soil seed bank, complete ban on collection of medicinal plants, fuelwoods, protection of species-specific habitats, and livestock management in adjacent villages. The study further recommends the use of alternative non-conventional source of energy such as LPG or solar in the local communities which could diminish the burden on adjacent forests.

\section{CONCLUSION}

Assessment of tree species diversity, density and regeneration pattern under prevailing microenvironment is important for their sustainable utilization, management and conservation. The present study shows that on the whole regeneration status of tree species in the study area is fair and it may be due to ambient environment, biotic and abiotic factors that greatly affected the endurance of the seedlings. Moreover, regeneration pattern of four species shows poor or no regeneration that was affected by microenvironment and nature of local canopy, because germination and survival of these seedlings and sprouts mostly depend on the above two factors. However, rest of the species of the study sites were regenerating and their seedlings and sprouts have managed to survive because of their broad ecological amplitude and greater adaptability against biotic interferences. Overall, the studied forest area shows fair regeneration (35.71\% in RA, $56.25 \%$ in GR) followed by good regeneration $(35.71 \%$ in $\mathrm{RA}, 6.25 \%$ in GR), not regenerating (28.57\% in RA, $12.5 \%$ in GR) and poor regeneration (12.5\% only in GR). Therefore, the result of the present study on tree species diversity and its regeneration status in Kyongnosla Alpine Sanctuary provide a better scope for future researchers and policy makers who want to obtained more accurate data on forest inventory and its implication on further conservation strategies.

\section{ACKNOWLEDGEMENT}

Authors are thankful to Dr. A.A. Mao, Director, Botanical Survey of India, Kolkata for encouragement and providing necessary facilities. The authors express their gratitude to the Secretary -cum- Principal Chief Conservator of Forests, Department of Forest, Government of Sikkim for giving permission and logistic support. The authors are acknowledging the financial grant of Ministry of Environment, Forest, and Climate Change (MoEF \& CC), Government of India under "National Mission on Himalayan Studies" Scheme. (NMHS/2015-16/LG-05). Authors are thankful to the anonymous reviewers for constructive comments and suggestions.

The authors declare no conflict of interest.

\section{REFERENCES}

Adhikari, B.S., Rikhari, H.C., Rawat, Y.S., \& Singh, S.P. (1991). High altitude forests composition, diversity and profile structures in a part of Kumaun Himalaya. Tropical Ecology, 32, 86-97.

Allen, C.D., Breshears, D.D., \& McDowell, N.G. (2015). On underestimation of global vulnerability to tree mortality and forest die- 
off from hotter drought in the Anthropocene. Ecosphere,6(8),1-55.doi://10.1890/ES1500203.1.

Ballabha, R., Kuniyal, A., Tiwari, P. \& Tiwari, J.K. (2020) Forest structure and composition in the vicinity of Srinagar hydroelectric power project in Alaknanda valley, Garhwal Himalaya, India. Journal of Forest and Environmental Science, 36(2), 78-90. doi://10.7747/JFES.2020.36.2.78.

Bhat, J.A., Kumar, M., Negi, A.K., Todaria, N.P., Malik, Z.A., Pala, N.A., Kumar, A. \& Shukla, G. (2020). Species diversity of woody vegetation along altitudinal gradient of the Western Himalayas. Global Ecology and Conservation, 24, e01302, doi://10.1016/j.gecco.2020.e01302.

Bhattacharyya, D., \& Sanjappa, M. (2014). Rhododendron L. In M. Sanjappa \& A.R.K. Sastry (Ed.), Fascicles of flora of India, Fascicle 25 Ericaceae (pp.9-157). Kolkata, India: Botanical Survey of India.

Cobb, R.C., Ruthrof, K.X., Breshears, D.D., Lloret, F., Aakala, T., Adams, ... Zeppel, M.J.B. (2017). Ecosystem dynamics and management after forest die-off: A global synthesis with conceptual state-and-transition models. Ecosphere, 8(12), 1-17. doi: //10.1002/ ecs2.2034.

Dar, J.A., \& Sundarapandian, S. (2016). Patterns of plant diversity in seven temperate forest types of Western Himalaya, India. Journal of AsiaPacific Biodiversity, 9 (3), 280-292.

Das, Deep \& Rawat, Dinesh \& Maity, Debabrata \& Dash, Sudhansu Sekhar \& Sinha, B .K. (2020). Species richness patterns of different life-forms along altitudinal gradients in the Great Himalayan National Park, Western Himalaya, India. Taiwania. 65(2), 154-162. doi://10.6165/tai.2020.65.154.

Dash, S.S. (2012). Floristic composition of early recovery vegetation of traditional shifting cultivated areas of Kurung-Kumey District of Arunachal Pradesh. Indian Forester, 138(9), $767-775$.

Dash, S.S., \& Singh, P. (2011). Trees of Sikkim. In: M.L. Arrawatia \& S. Tambe (Eds.), Biodiversity of Sikkim: Exploring and conserving a global hotspot (pp.89-125). Gangtok, India: Department of Information and Public Relations, Government of Sikkim.

Dash, S.S.; Panday, S.; Rawat, D.S.; Kumar, V.; Lahiri, S.; Sinha, B.K. \& Singh, P. (2021). Quantitative assessment of vegetation layers in tropical evergreen forests of Arunachal Pradesh, Eastern Himalaya, India. Current Science, 120 (5), 850-858.
Dasila, K., Samant, S. S. \& Pandey, A. (2021). Studies on subalpine forests of Hamta Pass area in Himachal Pradesh, India with a focus on Betula utilis populations. Current Science, 120(5), 872-882.

Deb, P., \& Sundriyal, R.C. (2008). Tree regeneration and seedling survival patterns in old-growth lowland tropical rainforest in Namdapha National Park, north-east India. Forest Ecology and Management, 255, 3995-4006. doi://10.1016/j.foreco.2008.03.046.

Douglas, G.W., \& Bliss, L.C. (1977). Alpine and high sub-alpine plant communities of the north Cascades Range, Washington and British Columbia. Ecological Monographs, 47(2), 113150. doi://10.2307/1942614.

Gairola, S., Rawal, R.S., \& Todaria, N.P. (2008). Forest vegetation patterns along an altitudinal gradient in sub-alpine zone of west Himalaya, India. African Journal of Plant Science, 2(6), 4248.

Gairola, S., Rawal, R.S., Todaria, N.P., \& Bhatt, A. (2014). Population structure and regeneration patterns of tree species in climate-sensitive subalpine forests of Indian western Himalaya. Journal of Forestry Research, 25(2),343-349. doi://10.1007/s11676-014-0463-0.

Grumbine, R.E., Pandit, M.K. (2013). Threats from India's Himalayas dams. Science, 339, 36-37. doi://10.1126/science.1227211.

Hanief, M., Bidalia, A., Meena, A. \& Rao, K.S. (2016). Natural regeneration dynamics of dominant tree species along an altitudinal gradient in three different forest covers of Darhal watershed in north western Himalaya (Kashmir), India. Tropical Plant Research, 3(2), 253-262

Haq, S. M., Rashid, I., Khuroo, A. A., Malik, Z. A. \& Malik, A. H. (2019). Anthropogenic disturbances alter community structure in the forests of Kashmir Himalaya. Tropical Ecology, 60(4). doi://10.1007/s42965-019-00001-8.

Jain, S.K., \& Rao, R.R. (1977). A handbook of field and herbarium methods. New Delhi, India: Today \& Tomorrow's Printers and Publishers.

Khali, M., \& Bhatt, V. P. (2014). Community structure of Montane forest along the altitudinal gradient in Garhwal Himalaya, India. Journal of Ecology and The Natural Environment, 6(6), 205-214.

Kumar, S. \& Sharma, S. (2014). Diversity, disturbance and regeneration status of forests along an altitudinal gradient in paddar valley, North West Himalayas. Indian Forester, 140, 348-353. 
Kumari, S., Mehta, J.P., Shafi S. \& Dhiman, P. (2017). Phytosociological analysis of woody vegetation under burnt and unburnt oak dominated forest at Pauri, Garhwal Himalaya, India. Environment Conservation Journal, 18(3), 99-106.

Lahiri,S.\&Dash,S.S.(2021).Diversityof Rhododendron L. (Ericaceae) in the Dzongri Goecha La trekking trail of Khangchendzonga Biosphere Reserve, Sikkim, India. Pleione, 15(2), 223-232. doi://10.26679/Pleione.15.2.2021.223-232.

Maity, D., Maiti, G.G., \& Chauhan, A.S. (2018). Vascular plants of Kanchenjunga Biosphere Reserve, Sikekim. Kolkata: Botanical Survey of India.

Malik, Z.A., \& Bhatt, A.B. (2015). Phytosociological analysis of woody species in Kedarnath Wildlife Sanctuary and its adjoining areas in western Himalaya, India. Journal of Environmental Sciences, 31(3), 149-163. doi://10.7747/JFES.2015.31.3.149.

Malik, Z.A., \& Bhatt, A.B. (2016). Regeneration status of tree species and survival of their seedlings in Kedarnath Wildlife Sanctuary and its adjoining areas in Western Himalaya, India. Tropical Ecology, 57(4), 677-690.

Malik, Z.A. \& Nautiyal, M. (2016). Species richness and diversity along the altitudinal gradient in Tungnath, the Himalayan benchmark site of HIMADRI. Tropical Plant Research, 3, 396-407.

Malik, Z.A., Hussain, A., Iqbal, K. \& Bhatt, A.B. (2014). Species richness and diversity along the disturbance gradient in Kedarnath Wildlife Sanctuary and its adjoining areas in Garhwal Himalaya, India. International Journal of Current Research, 6(12), 10918-10926.

Mao, A.A., Dash, S.S., \& Singh, P. (2017). Rhododendrons of North-East India: A pictorial handbook. Kolkata: Botanical Survey of India.

McCune, B. \& Mefford, M.J. (2016). PC-ORD Multivariate analysis of ecological data. Version 7. MjM Software Design, Gleneden Beach, Oregon, U.S.A.

Mir, N.A. Masoodi, T.H. Geelani, S.M. Wani, A.A, \& Sofi, P.A. (2017). Regeneration status of bhojpatra (Betula utilis) forest in north western Himalayas of Kashmir valley, India. Indian Journal of Agricultural Sciences, 87(7), 59-64.

Misra, R. (1968). Ecology work book. Calcutta, India: Oxford and IBH Publishing Co.

Mittal, A., Singh, N. \&Tiwari, A. (2020). Quantitative analysis and regeneration status of forest trees species in Kumaun Central Himalaya. Indian Journal of Ecology, 47(2), 507-513.
Negi, V.S.; Giri, L. \& Sekar, K.C. (2018). Floristic diversity, community composition and structure in Nanda Devi National Park after prohibition of human activities, Western Himalaya, India. Current Science, 115(6), 25.

Odum, E.P. (1971). Fundamentals of ecology. Philadelphia: Saunders Company.

Pala, N.A., Negi, A.K., Gokhale, Y. \& Todaria, N. P. (2013). Tree regeneration status of sacred and protected landscapes in Garhwal Himalaya, India. Journal of Sustainable Forestry, 32, 230246. doi://10.1080/10549811.2013.762492.

Panda, S., \& Sanjappa, M. (2014). Lyonia nutt. In M. Sanjappa \& A.R.K. Sastry (Eds.), Fascicles of flora of India, Fascicle 25 Ericaceae (pp.229-241). Kolkata, India: Botanical Survey of India.

Pandey, A., Badola, H.K., Rai, S., \& Singh, S.P. (2018a). Timberline structure and woody taxa regeneration towards treeline along latitudinal gradients in Khangchendzonga National Park, Eastern Himalaya. PLoS One, 13(11), 1-20. doi://10.1371/journal.pone.0207762.

Pandey, A., Rai, S., \& Kumar, D. (2018b). Changes in vegetation attributes along an elevation gradient towards timberline in Khangchendzonga National Park, Sikkim. Tropical Ecology, 59(2), 259-271.

Pant, S., \& Samant, S.S. (2012). Diversity and regeneration status of tree species in Khokhan Wildlife Sanctuary, north-western Himalaya. Tropical Ecology, 53(3), 317-331.

Paul, A., Khan, M.L., \& Das, A.K. (2018). Population structure and regeneration status of rhododendrons in temperate mixed broadleaved forests of western Arunachal Pradesh, India. Geology, Ecology, and Landscapes, 3(3), 1-19. doi://10.1080/24749508.2018.152 5671.

Pielou, E.C. (1966). The measurement of diversity in different types of biological collections. Journal of Theoretical Biology, 13, 131-144.

Rawat, D.S., Dash, S.S., Sinha, B.K., Kumar, V., Banerjee, A., \& Singh, P. (2018). Community structure and regeneration status of tree species in Eastern Himalaya: A case study from Neora Valley National Park, West Bengal, India. Taiwania, 63(1), 16-24. doi:// 10.6165/tai.2018.63.16.

Rawat, D.S., Tiwari, P., Das, S.K., \& Tiwari, J.K. (2020) Tree species composition and diversity in montane forests of Garhwal Himalaya in relation to environmental and soil properties. Journal of Mountain Science, 17(12), 3097-3111. doi://10.1007/s11629-019-5761-8. 
Rawat, V.S. \& Chandra, J. (2012). Tree layer vegetational analysis in temperate forest of Uttarakhand. Nature and Science, 10(10),167-171

Shafi, S., Mehta, J.P., Kumari, S. \& Dhiman, P. (2017). Phytosociological analysis of woody species under burnt and unburnt communities at Pauri Garhwal, Western Himalaya, India. ENVTS Bulletin Himalayan Ecology, 25, 98-105.

Shannon, C.E., \& Wiener, W.E. (1963). The mathematical theory of communities. Urbana: University of Illinois Press.

Sharma, C. M., Mishra, A. K., Tiwari, O.P., Krishan, R., \& Rana Y. S. (2018). Regeneration patterns of tree species along an elevational gradient in the Garhwal Himalaya. Mountain Research and Development, 38(3), 211-219. doi://10.1659/ MRD-JOURNAL-D-15-00076.1.

Sharma, P., Samant, S. S., \& Lal, M. (2017). Assessment of plant diversity for threat elements: A case study of Nargu Wildlife Sanctuary, north western Himalaya. Ceylon Journal of Science, 46(1), 75-95. doi://10.4038/ cjs. v46i1.7420.

Simpson, E.H. (1949). Measurement of diversity. Nature, $163(4148), \quad 688$. doi://10.1038/163688a0.

Singh, P., \& Sanjappa, M. (2011). Flowering plants of Sikkim- An analysis. In M.L. Arrawatia, \& S. Tambe (Eds.). Biodiversity of sikeim exploring and conserving a global hotspot (pp. 6588). Gangtok: Department of Information and Public Relations, Government of Sikkim.

Singh, S., Malik, Z.A., \& Sharma, C.M. (2016). Tree species richness, diversity, and regeneration status in different oak (Quercus spp.) dominated forests of Garhwal Himalaya, India. Journal of Asia-Pacific Biodiversity, 9(3), 293-300. doi:// 10.1016/j.japb.2016.06.002.

Sinha, S.; Badola, H.K.; Chhetri, B.; Gaira, K.S.; Lepcha, J.; Dhyani, P.P. (2018). Effect of altitude and climate in shaping the forest compositions of Singalila National Park in Khangchendzonga Landscape, Eastern Himalaya, India. Journal of Asia-Pacific Biodiversity, 2(1), 267-275. doi://10.1016/j. japb.2018.01.012.
Sundriyal, R.C., \& Bisht, N.S. (1988). Tree structure, regeneration and survival of seedlings and sprouts in high montane forests of the Garhwal Himalayas, India. Vegetatio, 75, 87-90. doi://10.1007/BF00044630.

Tewari, A., Bhatt, J., Mittal, A., Singh, N. \& Tamta, K.K. (2016). Regeneration issues and indicators of seed maturity in Mallotus phillipensis Muel. Arg. in the tropical Forests of Uttarakhand. Ecology Environment and Conservation, 22(2), 767-773.

Tewari, A., Mittal, A. \& Singh, N. (2017). Seed maturation timing in Quercus leucotrichophora A. camus along an altitudinal gradient in Uttarakhand Himalaya. Environment Conservation Journal, 18(3), 53-59.

Tiwari, O.P., Rana, Y.S., Krishan, R., Sharma, C.M., \& Bhandari, B.S. (2018). Regeneration dynamics, population structure, and forest composition in some ridge forests of the western Himalaya, India. Forest Science and Technology, 14(2), 66-75. doi://10.1080/2158 0103.2018.1447517.

Whittaker, R.H. (1972). Evolution and measurement of species diversity. Taxon, 21(2/3), 213-215.

Yam, G. \& Tripathi, O. (2016). Tree diversity and community characteristics in Talle Wildlife Sanctuary, Arunachal Pradesh, Eastern Himalaya, India. Journal of AsiaPacific Biodiversity, 9 (2). doi://0.1016/j. japb.2016.03.002. 


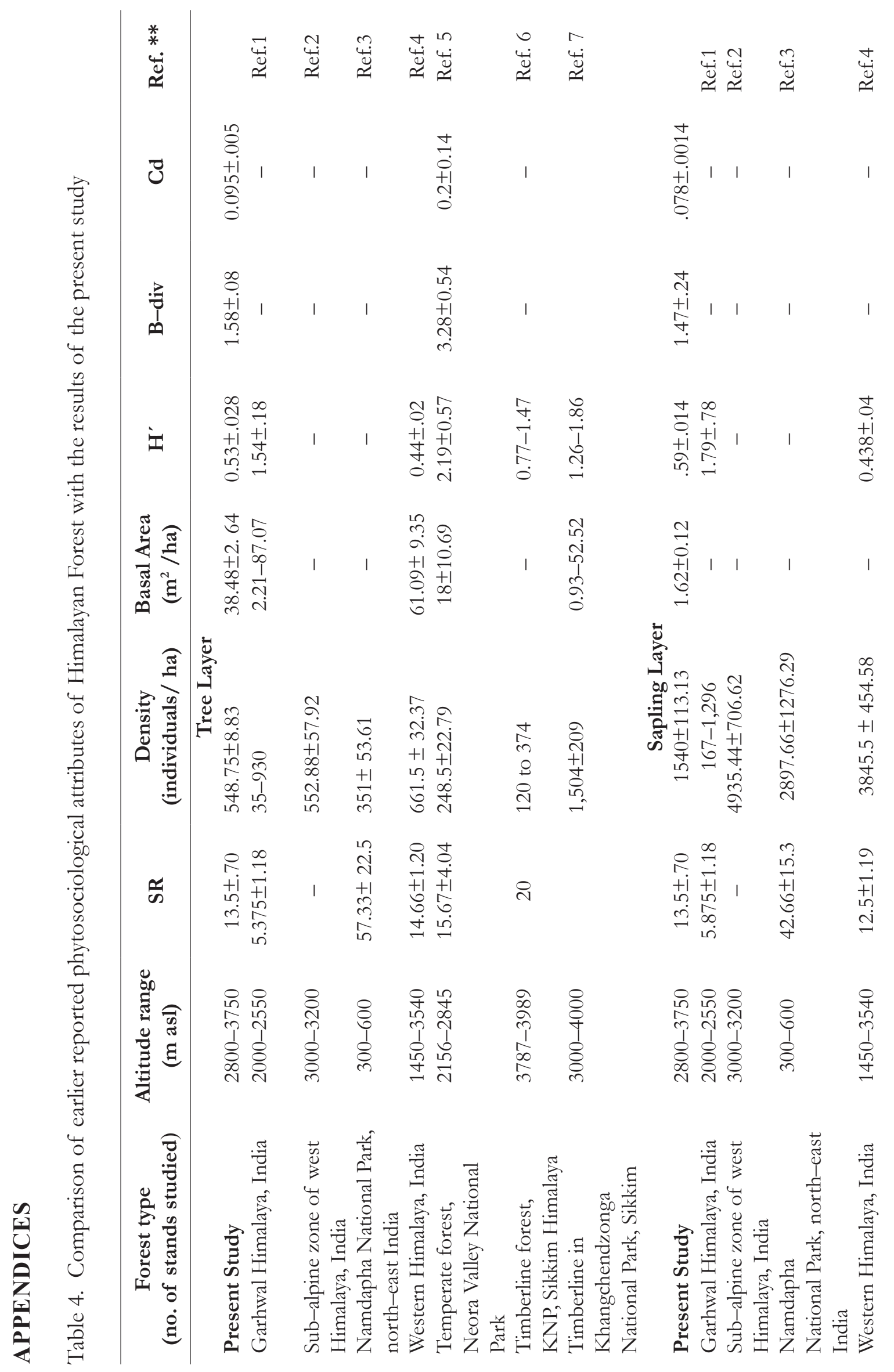




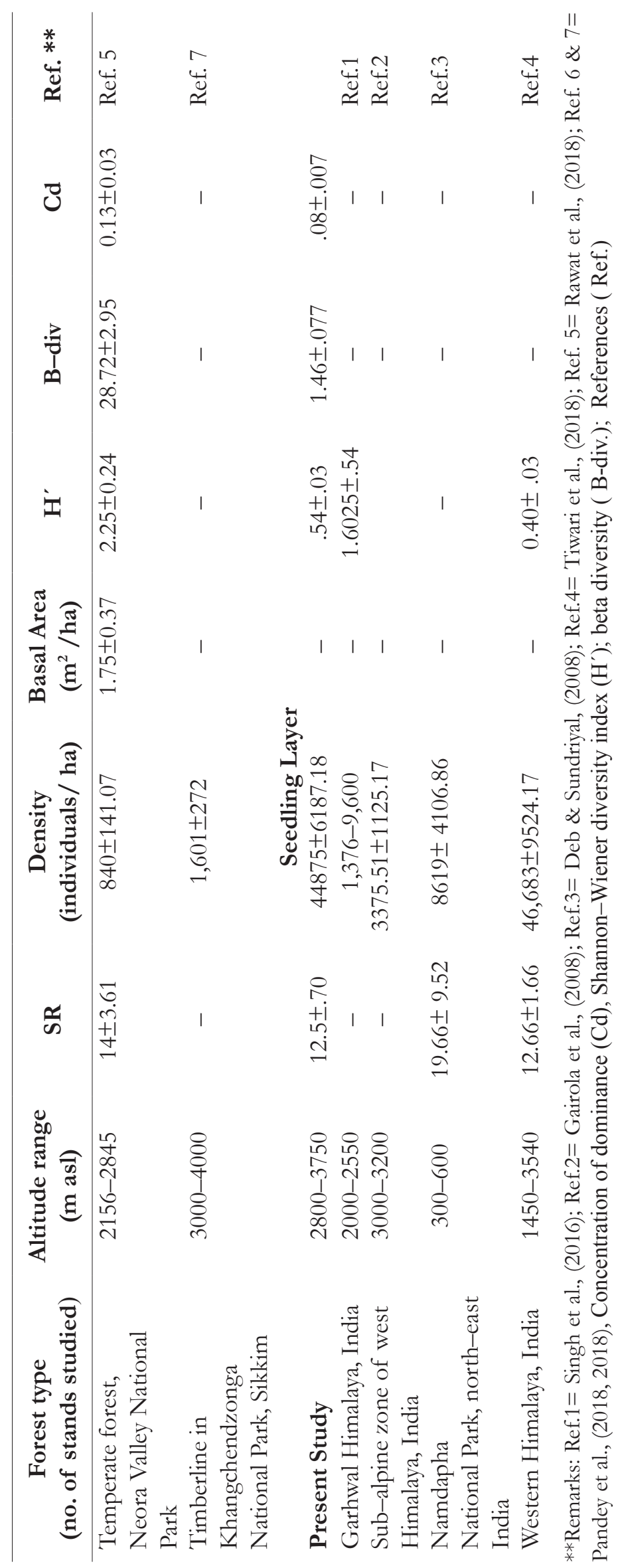

